\title{
AKAD JUAL BELI MURABAHAH DITINNJAU DARI PERLAKUAN AKUNTANSI BERDASARKAN PSAK 102 PADA LEMBAGA SYARIAH
}

\author{
Ahmad Fajar Firmansyah \\ Fakultas Ekonomi Universitas Islam Negeri Maulana Malik Ibrahim Malang \\ Jl. Gajayana No. 50 Malang \\ Email: firmansyahfajar55@gmail.com
}

Abstract

The implementation of murabahah financing at PT BRI Syariah Branch Bululawang-Malang and BMT Maslahah Sidogiri Branch BululawangMalang use the general implementation, that is selling goods. This study aims to determine the implementation of murabahah financing at PT BRI Syariah and BMT Maslahah Sidogiri. This research used the method of qualitative approach by looking at the relevant data and conducting interviews to the employees who take care of the financial part in the two institutions. This study investigated the implementation of murabahah financing that occurred in PT BRI Syariah and BMT Maslahah Sidogiri and evaluated the suitability of murabahah financing implementation with PSAK No. 102. The Results of this research showed that the implementation of murabahah financing that occurred in PT BRI Syariah and BMT Maslahah Sidogiri is buying and selling. The accounting treatment of murabahah including the recognition, measurement and presentation carried out by PT BRISyariah and BMT Maslahah Sidogiri were less in accordance with PSAK No. 102.

Keywords: Murabahah financing, PSAK No. 102

Abstrak

Penerapan pembiayaan maurabahah pada PT BRI Syariah Cabang BululawangMalang dan BMT Maslahah Sidogiri cabang Bululawang-Malang mengunakan 
penerapan pada umumnya yaitu jual beli barang. Penelitian ini bertujuan untuk mengetahui penerapan pembiayaan murabahah pada PT BRI Syariah dan BMT Maslahah Sidogiri. Penelitian ini mengunakan metode pendekatan kualititif yaitu dengan cara melihat data-data terkait dan melakukan wawancara kepada karyawan yang mengurus bagian keuangan di dua lembaga tersebut. Penelitian ini mengetahui penerapan pembiayaan murabahah yang terjadi di PT BRI Syariah dan BMT Maslahah Sidogiri dan mengevaluasi kesesuain penerapan pembiayaan murabahah dengan PSAK No. 102. Hasil penelitian dapat diketahui bahwa penerapan pembiayaan murabahah yang terjadi di PT BRI Syariah dan BMT Maslahah Sidogiri adalah jual beli. Perlakuan akuntansi murabahah meliputi pengakuan, pengukuran dan penyajian yang di lakukan oleh PT BRI syariah dan BMT Maslahah Sidogiri kurang sesuai dengan PSAK No. 102.

Kata kunci: Pembiayaan Murabahah, PSAK No. 102

\section{PENDAHULUAN}

Murabahah adalah akad jual beli barang dengan harga jual sebesar biaya perolehan ditambah keuntungan yang disepakati dan penjual harus mengungkapkan biaya perolehan barang tersebut kepada pembeli (PSAK 102 paragraf 5). Definisi ini menunjukan bahwa transaksi murabahah tidak harus dalam bentuk pembayaran tangguh (kredit), melainkan dapat juga dalam bentuk tunai setelah menerima barang, ditangguhkan dengan mencicil setelah menerima barang, ataupun ditangguhkan dengan membayar sekaligus di kemudian hari (PSAK 102 paragraf 8).

Pembiayaan yang paling dominan dalam perbankan syariah adalah murabahah. Karim (2006:113) dan Makhalul (2002:38-39) menyimpulkan bahwasanya murabahah merupakan salah satu produk penyaluran dana yang cukup digemari oleh masyarakat. Perkembangan pembiayaan murabahah dari tahun ke tahun mengalami peningkatan terbukti dari data statistik perbankan Indonesia yang dapat dilihat pada kenaikan persentase mulai dari tahun 2005 sampai 2011 pada tahun 2005 yaitu $0,312 \%$ kemudian tahun 2006 mengalami peningkatan $0,458 \%$ pada tahun 2007 dan 2008 tidak mengalami kenaikan tetap pada $0,562 \%$ pada tahun 2009 naik 0,770\% pada tahun 2011 0,895 dan terakhir pada 2011 peningkatan 1\% dari tahun 2005 sampai 2011 mengalami peningkatan yang cukup signifikan. (BI, Statistik Perbankan Syariah, Januari 2012)

Perkembangan produk pembiayaan murabahah di BRI syariah, dalam produk ini terjadi transaksi jual beli antara pembeli (nasabah) dan penjual (bank). Bank dalam hal ini memberikan barang yang dibutuhkan nasabah (nasabah yang menentukan spesifikasinya) dan menjualnya pada nasabah dengan harga ditambah keuntungan. Dari produk bank menerima laba atas jual beli yang harga pokoknya samasama diketahuai oleh kedua belah pihak. 
Selain perbankan syariah lembaga keuangan lainnya seperti Baitul Maal wat Tamwil (BMT) di Indonesia memiliki potensi yang sangat besar, karena penduduknya kebanyakan beragama islam. Pada perkembangannya produk murabahah dalam menyalurkan dana dan pembiayaan secara garis besar yang dikutip dari bapak Marzukki selaku kepala cabang Bululawang BMT Maslahah Sidogiri dalam wawancara awal kami bahwa pembiayaan produk murabahah sekitar $80 \%$ lebih diminati oleh masyarkat, produk murabahah yaitu transaksi pembiayaan yang ditujukan untuk memiliki barang dilakukan dengan prinsip jual beli yaitu dilaksnakan sehubungan dengan adanya perpindahan hak kepemilikan barang atau benda. Tingkat keuntungan BMT ditentukan di depan dan menjadi bagian harga atas barang yang dijual.

Penelitian dengan topik murabahah telah banyak dilakukan, penelitian yang memfokuskan pada penetapan harga jual dan penerapan PSAK 102 antara lain Fauzan (2011). Oktavia (2010) yang melakukan penelitian perbandingan PSAK 102 dengan perlakuan akuntansi murabahah di koperasi syariah Ben Iman. Sultony (2012) Analisis kesesuaian PSAK No. 102 terhadap perlakuan akuntansi murabahah pada PT. BTN Syariah Jakarta. Berdasarkan penelitian sebelumnya, belum ada yang meneliti tentang perlakuan akuntansi terhadap jual beli murabahah berdasarkan PSAK No. 102 pada Bank Umum Syariah (BUS) dan Baitul Maal wat Tamwil (BMT). Kami mengambil obyek penelitian di BUS karena lembaga yang sudah diawasi oleh Otoritas Jasa Keuangan (OJK) dan Bank Indonesia (BI) sedangkan BMT lembaga mikro yang masih belum diawasi oleh OJK dan BI Maka peneliti menfokuskan bagaimana penerapan perlakuan akuntansi jual beli murabahah pada PT. Bank BRISyariah cabang Malang dan BMT Maslahah Sidogiri cabang Malang telah sesuai dengan PSAK No. 102?

\section{TINJAUAN PUSTAKA}

\section{Pengertian Jual Beli Murabahah}

Jual beli dapat diartikan sebagai pertukaran harta atas dasar saling rela. Jual beli adalah proses pemindahan hak milik (barang atau harta) kepada pihak lain dengan menggunkan uang sebagai alat tukarnya (Widodo,2000:48). Prinsip jualbeli dilaksanakan sehubungan dengan adanya perpindahan kepemilikan barang. Salah satu skim fiqh yang populer digunakan oleh lembaga keuangan syariah antara lain BUS dan BMT adalah skim jual-beli murabahah.

Pengertian Murabahah adalah "akad jual beli barang dengan harga jual sebesar biaya perolehan ditambah keuntungan yang disepakati dan penjual harus mengungkapkan biaya perolehan barang tersebut kepada pembeli" (IAI, 2007b). Sabiq (2008) menjelaskan jual beli sebagai pemindahan sauatu kepemilikan dengan suatu ganti yang dapat dibenarkan secara syariah. Akad murabahahmerupakan akad yang diperbolehkan pelakunya memperoleh keuntungan karena termasuk 
kategori tijarah. Akad yang termasuk kategori tijarah pada satu waktu dapat dipindahkan menjadi kategori tabarru' tidak diperbolehkan menjadi sifat tijarah (Nurhayati \& Wasilah, 2012)

\section{Pengertian Murabahah}

Menurut Al-muslih dan Ash shawi (2004) murabahah secara bahasa adalah bentuk mutual (bermakna saling) dari kata Ribh yang artinya keuntungan, yakni pertambahan nilai modal (jadi artinya saling mendapatkan keuntungan) menurut termilogy ilmu fiqih artinya murabahah

Murabahah berasal dari kata "Ribh" yang berarti keuntungan, laba, atau tambahan. Murabahah faktanya adalah suatu istilah dalam fiqih Islam yang menunjukan suatu jenis jual beli yang tidak ada kaitanya sama sekali dengan pembiayaan. Murabahah dalam pengertian aslinya menurut Islam adalah "is simply a sale”, jual beli. Pembayaran, bisa dilakukan secara tunai (as spot) atau nanti pada suatu tanggal telah disepakati (a subsequents date) para pihak.(Sugeng, 2010:48).

Karim (2006:113) menjelaskan bahwa murabahah adalah akad jual dengan menyatakan perolehan dan keuntungan (margin) yang disepakati oleh penjual dan pembeli. Akan ini merupakan bentuk dari natural certainty contract, karena dalam murabahah ditentukan beberapa required rate of return-nya (keuntungan yang ingin diperoleh). Jadi karakteristik dari murabahah adalah penjual harus memberitahu pembeli tentang harga pembelian barang dan menyatakan jumlah keuntungan yang ditambahkan pada biaya tersebut.

Murabahah adalah akad jual beli barang dengan harga jual sebesar biaya perolehan ditambah keuntungan yang disepakati dan penjual harus mengungkapkan biaya perolehan barang tersebut kepada pembeli (PSAK 102 paragraf 5).

\section{A. Dasar Hukum Jual Beli Murabahah dalam Al Quran dan Al Hadist}

Berikut beberapa ayat Al-Qur'an yang menjelaskan tentang Jual beli Murabahah

1) Firman Allah QS. Al-Baqarah (2) ayat 275:

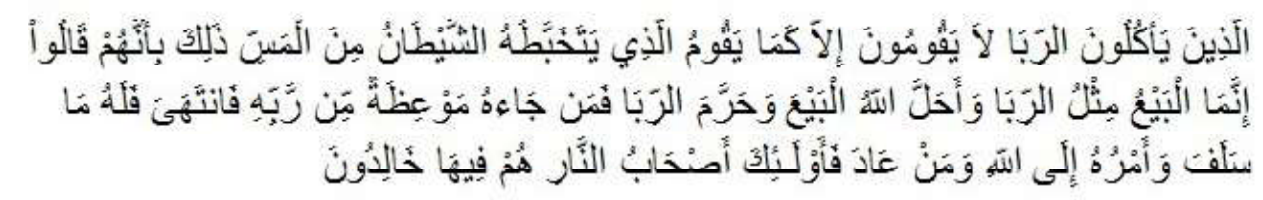

Artinya: "Orang-orang yang makan (mengambil) riba[174] tidak dapat berdiri melainkan seperti berdirinya orang yang kemasukan syaitan lantaran (tekanan) penyakit gila[175]. keadaan mereka yang demikian itu, adalah disebabkan mereka berkata (berpendapat), sesungguhnya jual beli itu sama dengan riba, padahal Allah telah 
menghalalkan jual beli dan mengharamkan riba. orang-orang yang telah sampai kepadanya larangan dari Tuhannya, lalu terus berhenti (dari mengambil riba), Maka baginya apa yang Telah diambilnya dahulu[176] (sebelum datang larangan); dan urusannya (terserah) kepada Allah. orang yang kembali (mengambil riba), Maka orang itu adalah penghuni-penghuni neraka; mereka kekal di dalamnya." (2:275)

Dalam (Tafsir Al-Ahkam, 2006: 163-164) riba itu ada dua macam: nasiah dan fadhl. riba nasiah ialah pembayaran lebih yang disyaratkan oleh orang yang meminjamkan. riba fadhl ialah penukaran suatu barang dengan barang yang sejenis, tetapi lebih banyak jumlahnya Karena orang yang menukarkan mensyaratkan demikian, seperti penukaran emas dengan emas, padi dengan padi, dan sebagainya. riba yang dimaksud dalam ayat Ini riba nasiah yang berlipat ganda yang umum terjadi dalam masyarakat Arab zaman Jahiliyah. Maksudnya: orang yang mengambil riba tidak tenteram jiwanya seperti orang kemasukan syaitan. Riba yang sudah diambil (dipungut) sebelum turun ayat ini, boleh tidak dikembalikan.

2) Firman Allah QS. Ali Imron (3) ayat 130:

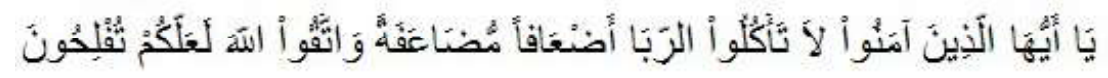

Artinya: "Hai orang-orang yang beriman, janganlah kamu memakan riba dengan berlipat ganda dan bertakwalah kamu kepada Allah supaya kamu mendapat keberuntungan. "(3:130)

Yang dimaksud riba di sini ialah riba nasi'ah. menurut sebagian besar ulama bahwa riba nasi'ah itu selamanya Haram, walaupun tidak berlipat ganda. Riba itu ada dua macam: nasiah dan fadhl. riba nasiah ialah pembayaran lebih yang disyaratkan oleh orang yang meminjamkan. Riba fadhl ialah penukaran suatu barang dengan barang yang sejenis, tetapi lebih banyak jumlahnya Karena orang yang menukarkan mensyaratkan demikian, seperti penukaran emas dengan emas, padi dengan padi, dan sebagainya. Riba yang dimaksud dalam ayat ini riba nasiah yang berlipat ganda yang umum terjadi dalam masyarakat Arab zaman jahiliyah. (Tafsir Ibnu Kasir, 2000: 140)

3) Firman Allah QS. An-Nisaa' (4) ayat 29:

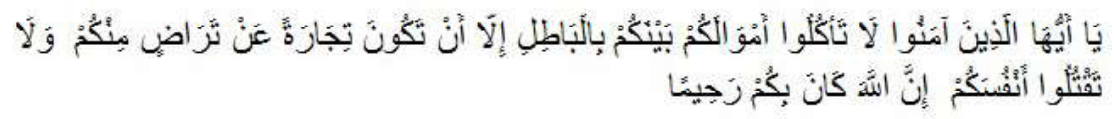


Artinya: "Hai orang-orang yang beriman, janganlah kamu saling memakan harta sesamamu dengan jalan yang batil, kecuali dengan jalan perniagaan yang berlaku dengan suka sama-suka di antara kamu. dan janganlah kamu membunuh dirimu; Sesungguhnya Allah adalah Maha Penyayang kepadamu."(4:29)

Lafaz tijaratan dapat pula dibaca tijaratun, ungkapan ini merupakan bentuk istisna munqoti'. Seakan-akan dikatakan. 'janganlah kalian menjalankan usaha yang menyebabkan perbuatan yang diharamkan tetapi berniagalah menurut peraturan yang diakui oleh syariat, yaitu perniagaan yang dilakukan suka sama suka di antara pihak pembeli dan pihak penjual. (Tafsir Ibnu Kasir, 2001: 38)

4) Hadist Nabi dari Abdullah bin Umar Radhiyallahu Anhuma:

Abdullah bin Umar Radhiyallahu Anhuma, dari Rasullah Shallallahu Alaihi wa Sallam, beliau bersabda, "Jika dua saling berjual beli, maka masing-masing di antara keduanya mempunyai hak pilih selagi keduanya belum berpisah, dan keduanya sama-sama mempunyai hak, atau salah seorang di antara keduanya belum berpisah, dan keduanya memberi pilihan kepada yang lain”. Beliau Bersabda, "Jika salah seorang di antara keduanya memberi pilihan kepada yang lain, lalu keduanya menetapkan jual beli atas dasar pilihan itu, maka jual beli menjadi wajib." (HR Bukhari-Muslim)

Dalam jual beli, dibolehkan memilih akan melanjutkan jual beli atau akan membatalkannya. Karena terjadinya suatu hal, khiar dibagi menjadi 3 macam berikut ini: 1. Khiar majelis, artinya antara penjual dan pembeli boleh memilih akan melanjutkan jual beli atau membatalkannya, selama keduanya masih ada dalam satu tempat (majelis), khiar majelis dapat dilakukan dalam berbagai jual beli. 2. Khiar syarat, yaitu penjualan yang di dalamnya disyaratkan sesuatu yang baik oleh penjual maupun pembeli, seperti seseorang berkata, "saya jual rumah ini dengan harga Rp. 100.000.000,dengan syarat khiar selama 3 hari". Khiar aib, artinya dalam jual beli ini disyaratkan kesempurnaan benda-benda yang akan dibeli, seperti seorang berkata, "saya beli mobil ini seharga sekian, bila mobil ini cacat akan saya kembalikan". (Hendi, 2008: 84)

\section{Perlakuan Akuntansi Murabahah Menurut PSAK 102}

Pada akuntansi murabahah Bank Umum Syariah (BUS) atau BMT dapat bertindak sebagai penjual dan juga pembeli, sebagai penjual apabila BUS dan BMT menjual barang kepada nasabah, sedangkan apabila BUS atau BMT berperan 
sebagai pembeli maka membeli barang kepada pemasok untuk dijual kepada nasabah. Perlakuan akuntansi murabahah di BUS dan BMT dalam PSAK No. 102 dan PAPSI 2003, PSAK No. 102 mengantikan PSAK No. 59 yang berhubungan dengan pengakuan, pengukuran, penyajian dan pengungkapan murabahah. Standar ini mengatur berbagai definisi terkait transaksi murabahah dan memberikan penjelasan tentang karakteristik transaksi murabahah sebagaimana yang terdapat pada fatwa DSN.

Perbedaan cakupan akuntansi murabahah dalam PSAK No. 102 dengan akuntansi murabahah dalam PSAK No. 59 adalah PSAK No. 59 hanya membahas akuntansi muarabahah dari pihak Bank syariah sebagai penjual dan akuntansi pada pihak pembeli (nasabah) tidak dibahas dalam PSAK No. 59 tersebut. Sedangkan dalam PSAK No. 102 diatur akuntansi murabahah dari pihak penjual dan akuntansi murabahah dari pembeli. PSAK No. 102 tentang akuntansi murabahah hanya membahas akuntansi dari pihak penjual dan akuntansi murabahah dari pembeli atas barang dagangan yang siap untuk dijual (bukan barang yang dalam proses pembuatan) oleh karena itu dalam PSAK No. 102 tidak membahas akuntansi pada sisi pemasok yang pengadaan barang dilakukan dengan proses dibuat sendiri. (Wiroso, 2011:79).

Dari berbagai transaksi yang perlu untuk diketahui oleh penjual dalam transaksi antara lain penerimaan uang muka murabahah, pengakuan dan pengukuran terkait asset murabahah pada saat perolehan, aset murabahah setelah perolehan jika terjadi penurunan niali aset atau diskon pembelian. Adapun pada saat akad dilakukan, standar ini memberikan panduan tentang pengakuan dan pengukuran piutang murabahah, keuntunngan murabahah, denda jika pembeli lalai dalam melakukan kewajibannya, potongan pelunasan piutang murabahah dan potongan angsuran murabahah. PSAK No. 102 juga memberikan panduan untuk pembeli akhir. Beberapa hal yang secara khusus diatur dalam standar ini adalah utang yang timbul dari transaksi, aset yang diperoleh beban murabahah, diskon pembelian yang diterima dari penjual, denda yang dibayar akibat kelalaian dan potongan uang muka akibat pembatalan pembelian.

\section{METODE PENELITIAN}

\section{Jenis Penelitian dan Pendekatan Penelitian}

Jenis penelitian ini merupakan jenis penelitian kualitatif yaitu berupa suatu prosedur penelitian yang menghasilkan data deskriptif berupa ucapan atau tulisan dari perilaku yang dapat diamati dari subjek itu sendiri (Furhan, 1992:21). studi kasus dilakukan untuk meneliti tentang analisa perlakuan jual beli murabahah berdasarkan PSAK No. 102 pada PT BRISyariah Bululawang-Malang dan BMT Sidogiri Bululawang-Malang. 


\section{Lokasi Penelitian}

Penelitian mengambil salah satu Bank Umum Syariah (BUS) dan Baitul Maal wat Tamwil (BMT). Bank Umum Syariah yaitu BRI syariah, karena BRI syariah merupakan bank milik pemerintah yang melandaskan operasionalnya pada prinsip syariah. Tepatnya mengambil salah satu cabang pembantu BRI syariah yang berlokasi di Bululawang-Malang yang beralamatkan di Jl. Bululawang Utara Rt. 15 RW. 4 Kecamatan Bululawang-Malang. Sedangkan untuk Baitul Maal wat Tamwil (BMT) yaitu BMT Maslahah Sidogiri cabang Bululawang-Malang.

Lokasi yang dijadikan penelitian adalah di pojok bursa efek UIN Maulana Malik Ibrahim Malang, Jl.Gajayana No.50 Malang dengan mencari data yang berkaitan dengan variabel-variabel yang akan diujikan diantaranya adalah perubahan kurs valuta asing, tingkat suku bunga, tingkat inflasi, dan arus kas perusahaan.

\section{Subyek Penelitian}

Subyek penelitian dalam penelitian ini adalah:

a. Responden merupakan orang-orang yang merespon dan menjawab setiap pertanyaan yang bisa berupa jawaban lisan melalui wawancara. Dalam penelitian ini yang menjadi responden adalah

1. Account officer (AO) pembiayaan murabahah pada Bank BRI Syariah cabang pembantu Bululawang-Malang dan BMT Sidogiri BululawangMalang.

2. Financing administration (administrasi pembiayaan/ADP), dimana sebyek menjelaskan bahwa terdapat biaya-biaya yang dibebankan kepada nasabah untuk mengantisipasi pembiayaan bermasalah.

b. Dokumen adalah sumber data yang berupa catatan dengan cara mencatat data-data yang sesuai dengan permasalahan dan penelitian yang dilakukan. Dokumen yang dibutuhkan berupa data tentang jual beli murabahah.

\section{Sumber dan Jenis Data}

Penelitian yang dilaksanakan berkaitan erat dengan data yang diperoleh sebagai dasar dalam pembahasan dan analisis. Sumber data penelitian merupakan faktor penting yang menjadi pertimbangan dalam menentukan metode pengumpulan data, sehingga menurut Nur dan Bambang (1999:146-147) sumber data terdiri atas:

1. Data Primer. Data primer merupakan sumber data penelitian yang diperoleh secara langsung dari sumber asli (tidak melalui media perantara). Data primer secara khusus dikumpulkan oleh peneliti untuk menjawab pertanyaan penelitian. Data primer diperoleh secara individu atau kelompok atau pada bagian yang berhubungan dengan pembiayaan murabahah tersebut. 
2. Data Sekunder. Data sekunder merupakan sumber data yang diperoleh peneliti secara tidak langsung melalui media perantara. Data sekunder umumnya berupa bukti, catatan atau laporan historis yang telah disusun dalam arsip (data dokumenter) yang dipublikasihkan dan tidak dipublikasikan seperti data umum perusahaan. Data sekunder yang diperoleh peneliti adalah berupa sejarah lokasi, visi dan misi, struktur organisasi serta job description yang digunakan Bank BRI syariah Bululawang-Malang dan BMT Sidogiri Bululawang-Malang.

\section{Teknik Pengumpulan Data}

Dalam pengumpulan data, teknik pengumpulan data yang digunakan penulis adalah melalui observasi, wawancara dan dokumentasi, yaitu penulis mengadakan dialog langsung dengan responden yang akan memberikan keterangan mengenai permasalahan yang akan diteliti. Selain itu juga menggunakan study documenter yaitu peneliti berusaha mempelajari berkas-berkas atau arsip-arsip yang ada pada PT Bank BRI syariah cabang Malang dan BMT Maslahah Sidogiri Cabang Malang yang berkaitan dengan penelitian tersebut.

1. Observasi. Pengertian observasi adalah teknik pengumpulan data, dimana peneliti maelakukan pengamatan secara langsung ke objek penelitian untuk melihat lebih dekat kegiatan yang dilakukan (Ridwan, 2004: 104)

2. Wawancara. Berdasarkan prosedurnya, wawancara dilakukan melaui tiga bentuk, yaitu wawancara terpimpin/terstruktur, wawancara bebas/tidak terstruktur, dan wawancara bebas termpimpin" (Narbuko dan Achmadi, 2007: 83). Dalam penelitian ini, peneliti menggunakan wawancara bebas terpimpin, yaitu kombinasi antara wawancara terpimpin dan wawancara bebas. Wawancara dilakukan dengan melibatkan informan penelitian.

3. Dokumentasi. Analisis dokumen dilakukan untuk mengumpulkan data yang bersumber dari arsip dan dokumen yang berasal dari dalam perusahaan yang sedang diteliti, dan berhubungan dengan penelitian. Pengumpulan data melalui dokumen akan memperkuat kredibilitas hasil penelitian dan wawancara (Sugiono, 2011:240)

\section{Fokus Penelitian}

Dalam penelitian ini, yang ditekankan oleh penulis adalah analisis tentang perlakuan jual beli murabahah berdasarkan PSAK No. 102 pada Bank BRI syariah Cabang Malang dan Baitul Maal wat Tamwil (BMT) Sidogiri cabang Bululawang Malang. 


\section{Model Analisis Data}

Jenis data yang digunakan dalam penelitian ini adalah data kualitatif dan data kuantitif. Analisa data dilakukan dengan "mencari dan menyusun secara sistematis data yang akan diperoleh dari lapangan dengan mengorganisasikan, memilih halhal yang penting dan akan dipelajari, dan membuat kesimpulan yang mudah dipahami baik bagi diri sendi maupun orang lain" (sugiyono, 2011: 244). Teknik analisis data yang digunakan sebagai berikut:

1. Tahap Pengumpulan Data

Proses pengambilan data kualitatif dilakukan dengan cara pengamatan terlibat yaitu dengan cara peneliti melibatkan diri dalam kegiatan perusahaan yang sedang diteliti. Menurut Muhammad Idrus (2009:149), pengamatan terlibat merupakan jenis pengamatan yang melibatkan perubahan pada kegiatan atau aktivitas yang bersangkutan dan tidak menyembunyikan diri. Harapan dilakukannya proses ini adalah peneliti dapat menemukan makna di balik fenomena yang disaksikannya, baik tentang perilaku, ucapan, ataupun simbol-simbol yang ada di perusahaan.

2. Tahap Reduksi Data

Menurut Muhammad idrus (2009:150) reduksi data dapat diartikan sebagai proses pemilihan, pemusatan perhatian pada penyederhanaan, pengabstrakan, dan transformasi data kassar yang muncul dari catatan-caatatan tertulis dari lapangan. Ciri-ciri reduksi data yaitu: a) membentuk analisa yang menajamkan, b) menggolongkan data, c) membuang data yang tidak perlu, d) memberikan gambaran yang lebih terarah tentang hasil pengumpulan, e) mempermudah peneliti untuk mencari kembali data apabila diperlukan.

3. Penyajian Data

Menurut Muhammad Idrus (2009:151), kegiatan reduksi data dan proses penyajian data adalah aktivitas-aktivitas yang terkait langsung dengan proses analisis data model interaktif. Dalam tahap ini, peneliti menyajikan perlakuan jual beli murabahah yang sesuai dengan standar akuntansi.

4. Verifikasi dan penarikan kesimpulan

Menurut Muhammad Idrus (2009:151) tahap akhir proses pengumpulan data adalah verifikasi dan penarikan kesimpulan, yang dimaknai sebagai penarikan arti data yang telah ditampilkan. Beberapa cara dilakuakan adalah melaukan pencatatan atas perlakuan akuntansi jual beli murabahah bedasarkan PSAK No. 102. 


\section{PEMBAHASAN}

\section{Analisis penerapan perlakuan akuntansi pembiayaan murabahah pada PT. Bank BRI syariah Kantor Cabang Pembantu Bululawang-Malang}

Berdasarkan hasil wawancara kami pada karyawan BRI syariah dapat diketahui bahwa BRI syariah sebagai penjual di dalam akad murabahah menerapkan metode pesanan mengikat, artinya bank akan melakukan perannya sebagai penjual apabila nasabah menginginkan suatu barang. BRI Syariah menggunakan metode pesanan mengikat karena bank menghindari risiko kerusakan dan penyusutan barang.

Nasabah yang menginginkan pembelian barang melalui akad murabahah di BRI syariah terlebih dahulu mengomunikasikan data diri dan data barang kepada bank. BRI syariah yang telah menerima data diri nasabah dan data barang pesanan akan memprosesnya lebih lanjut, dalam menjalankan pembiayaan murabahah BRI syariah menjual barang dengan menegaskan harga perolehan barang kepada nasabah dengan jujur dan nasabah akan membayar dengan harga lebih tinggi sebagai keuntungan (margin) bagi BRI syariah selaku penjual sesuai dengan kesepakatan antara pihak bank dan nasabah.

\section{Pengakuan pembiayaan murabahah menurut PT. Bank BRI Syariah kantor cabang pembantu Bululawang-Malang}

Pada saat perolehan, aset murabahah diakui sebagai persediaan sebesar biaya perolehan. Murabahah dapat dilakukan berdasarkan pesanan dan tanpa pesanan. Pada saat akad murabahah yang telah disetujui, piutang murabahah dicatat sebesar harga jual yaitu harga pokok di tambah dengan margin/keuntungan yang telah disepakati ketika akad. Diskon dapat diberikan sesuai dengan ketentuan yang berlaku namun tidak diperjanjikan diawal.

\section{Pengukuran pembiayaan murabahah menurut PT. Bank BRI Syariah kantor cabang pembantu Bululawang-Malang}

Diskon pembelian aset murabahah diakui sebagai pengurang biaya perolehan aset murabahah jika terjadi sebelum akad dan kewajiban kepada pembeli/nasabah jika terjadi setelah akad. Pada saat akad murabahah, piutang diakui sebesar biaya perolehan aset murabahah ditambah keuntungan/margin yang telah disepakti. Pelunasan dipercepat atau pelunasan sebelum jatuh tempo untuk piutang sesuai dengan masa jatuh tempo (biasa). Denda dikenakan jika pembeli lalai dalam melakukan kewajibannya sesuai dengan akad, dan denda yang diterima diakui sebagai dana kebajikan. 


\section{Penyajian Pembiayaan murabahah menurut PT. Bank BRI Syariah kantor cabang pembantu Bululawang-Malang}

BRI syariah menyajikan piutang murabahah sebesar nilai bersih yaitu nilai piutang murabahah setelah dikurangi dengan cadangan penyisihan kerugian. Margin murabahah ditangguhkan disajikan sebagai pos lawan piutang murabahah. BRI syariah menyajikan pendapatan murabahah ke dalam kategori pedapatan dari jual beli oleh BRI syariah disajikan secara akumulasi dengan akad jual beli pada laporan laba/rugi komprehensif dan secara khusus untuk pendapatan murabahah pada catatan atas laporan keuangan.

\section{Analisis penerapan perlakuan akuntansi pembiayaan murabahah pada BMT Maslahah Sidogiri kantor cabang Bululawang-Malang}

Berdasarkan hasil wawancara kami pada karyawan BMT Sidogiri dapat diketahui bahwa BMT sebagai penjual di dalam akad murabahah menerapkan metode pesanan mengikat, artinya bank akan melakukan perannya sebagai penjual apabila nasabah menginginkan suatu barang. BMT Maslahah Sidogiri akan melakukan pembelian barang apabila telah dipastikan ada nasabah yang akan memesan atau membeli membeli kembali barang tersebut secara akad murabahah. Dalam menjalankan pembiayaan murabahah, BMT Maslahah Sidogiri menjual barang dengan menegaskan harga perolehan barang kepada nasabah secara jujur dan nasabah membayar dengan harga lebih tinggi sebagai keunyungan (margin) bagi BMT selaku penjual sesuai dengan kesepakatan antara pihak BMT dan nasabah, pembayaran kewajiban dilakukan oleh nasabah secara tangguh atau cicilan.

Aplikasi pembiayaan murabahah pada BMT Maslahah Sidogiri dapat dikategorikan sebagai pembiayaan konsumtif. Pembiayaan konsumtif merupakan pembiayaan untuk keperluan konsumtif nasabah, antara lain: pembelian mobil, rumah dan keperluan konsumsi keseharian lainnya.

\section{Pengakuan pembiayaan murabahah menurut BMT Maslahah Sidogiri Kantor Cabang Pembantu Bululawang-Malang}

Pada saat perolehan, aset murabahahtidak diakui sebagai persediaan sebesar biaya perolehan. Murabahah dapat dilakukan berdasarkan pesanan dan tanpa pesanan. Pada saat akad murabahah yang telah disetujui, piutang murabahah dicatat sebesar harga jual yaitu harga pokok di tambah dengan margin/ keuntungan yang telah disepakati ketika akad. Diskon dapat diberikan sesuai dengan ketentuan yang berlaku namun tidak diperjanjikan diawal. 


\section{Pengukuran pembiayaan murabahah menurut BMT Maslahah Sidogiri kantor cabang pembantu Bululawang-Malang}

Diskon pembelian aset murabahah diakui sebagai pengurang biaya perolehan aset murabahah jika terjadi sebelum akad dan kewajiban kepada pembeli/nasabah jika terjadi setelah akad. Pada saat akad murabahah, piutang diakui sebesar biaya perolehan aset murabahah ditambah keuntungan/margin yang telah disepakti. Pelunasan dipercepat atau pelunasan sebelum jatuh tempo untuk piutang sesuai dengan masa jatuh tempo (biasa). Denda dikenakan jika pembeli lalai dalam melakukan kewajibannya sesuai dengan akad, dan denda yang diterima diakui sebagai dana kebajikan.

\section{Penyajian pembiayaan murabahah BMT Maslahah Sidogiri kantor cabang pembantu Bululawang-Malang}

Pencatatan untuk transaksi pelunasan angsuran oleh nasabah yang nilainya sebesar jumlah seluruh sisa pokok piutang ditambah dengan bonus margin yang telah diperhitungkan pada saat penyelesaian BMT hanya mengurangi pendapatan margin/keuntungan.

\section{Integrasi Penelitian Dalam Islam}

\section{Tentang pengakuan perlakuan akuntansi}

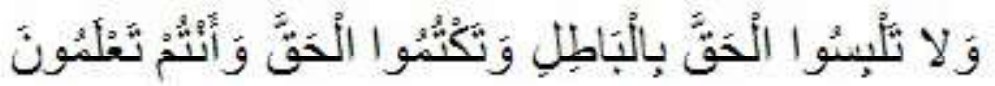

Artinya:Dan janganlah kalian campur adukan yang hak dengan yang batil,dan janganlah kalian menyembunyikan yang hak itu, sedangkan kalian mengetahuinya. (Al-Baqarah: 42)

Allah Swt melarang mereka dari kedua perkara tersebut secara bersamaan, dan memerintahkan mereka agar menampakan perkara yang hak dan menjelaskannya. Karena itu, Ad-Dahhak meriwayatkan dari Ibnu Abbas sehubungan dengan firman-Nya, yakni "Janganlah kalian campur adukkan yang hak dengan yang batil" (Al-Baqarah: 42), yakni janganlah kalian memalsukan yang hak dengan yang batil, yang benar dengan kedustaan.

\section{Tentang pengukuran perlakuan akuntansi}

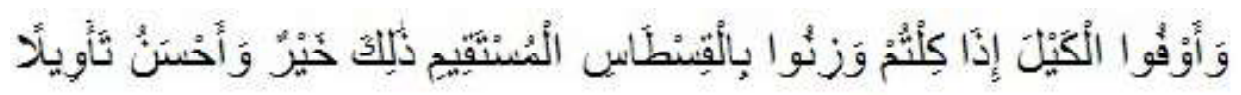


Artinya: Dan sempurnakanlah takaran apabila kamu menakar, dan timbanglah dengan neraca yang benar. Itulah yang lebih utama (bagimu) dan lebih baik akibatnya. (Al-Isra: 35)

Ibnu Abbas pernah berkata, "Hai para mawali (pelayan) sesungguhnya kalian diserahi dua perkara yang pernah mengakibatkan kebinasaan manusia di masa sebelum kalian, yaitu takaran dan timbangan.

Sa'id telah meriwayatkan dari Qatadah sehubungan dengan makna firmanNya: Itulah yang lebih utama (bagi kalian) dan lebih baik akibatnya. Yakni lebih utama bagi kalian dalam kehidupan dunia dan akhirat. Karena itulah dalam firman selanjutnya lebih baik akibatnya bagi kehidupan akhirat kalian.

\section{Tentang penyajian perlakuan akuntansi}

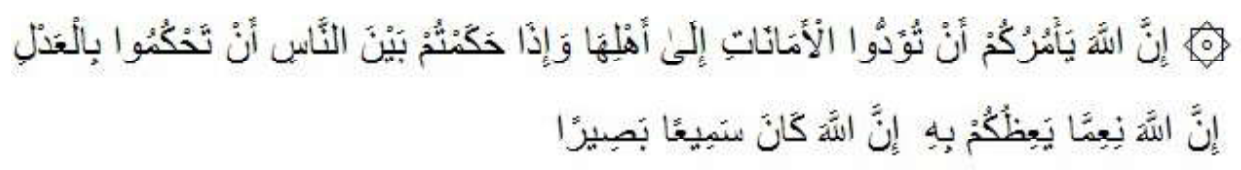

Artinya: Sesungguhnya Allah menyuruh kamu menyampaikan amanat kepada yang berhak menerimanya, dan (menyuruh kamu) apabila menetapkan hukum di antara manusia supaya kamu menetapkan dengan adil. Sesungguhnya Allah memberi pelajaran yang sebaik-baiknya kepadamu. Sesungguhnya Allah adalah Maha Mendengar lagi Maha Melihat. (An-Nisa': 58)

Di dalam hadist Al-Hasan, dari Samurah, disebutkan bahwa Rasulullah Saw. Telah bersabda yang artinya: "Sampaikan amanat itu kepada orang yang mempercayaimu, dan janganlah kamu berkhianat terhadap orang yang berkhianat kepadamu”.

Hadist riwayat Imam Ahmad dan semua pemilik kitab sunan. Makna hadist ini umum mencangkup semua jenis amanat yang diharuskan bagi manusia menyampaikannya.

\section{SIMPULAN}

Dalam penerapan pembiayaan murabahah pada PT BRI Syariah Cabang Bululawang-Malang dan BMT Maslahah Sidogiri Cabang Bululawang-Malang belum sesuai dengan prinsip syariah. Karena dalam penerapannya sama-sama menetapkan harga beli ditambah margin keuntungan yang di tentukan oleh pihak bank. Pembiayaan yang ada di PT BRI Syariah Cabang Bululawang-Malang dan BMT Maslahah Sidogiri Cabang Bululawang-Malang menerapkan murabahah 
pesanan. PT BRI Syariah dan BMT Maslahah Sidogiri hanya melakukan pembelian barang jika ada nasabah atau anggota yang akan membeli barang kembali secara akad murabahah. Dalam menjalankan pembiayaan murabahah, PT BRI syariah dan BMT Maslahah Sidogiri menjual barang dengan menegaskan harga perolehan kepada nasabah dan nasabah membayar dengan harga lebih sebagai keuntungan atau margin bagi PT BRI syariah dan BMT Maslahah Sidogiri selaku penjual sesuai dengan kesepakatan antara pihak PT BRI syariah dan BMT Maslahah Sidogiri sebagai penjual dan nasabah. Pembayaran dilakukan oleh nasabah secara tangguhan atau cicilan.

Kesesuaian pembiayaan murabahah dengan PSAK No.102 kurang sesuai antara lain di pengukuran pendapatan pembiayaan murabahah yang diakui pada saat terjadi pembayaran piutang pada PT BRI syariah dan BMT Maslahah Sidogiri.

Saran yang ingin penulis sampaikan dari hasil penelitian yang telah penulis lakukan adalah adanya penunggakan pembayaran kewajiban yang dilakukan oleh nasabah dan pembatalan barang nasabah, maka dari itu lembaga keuangan syariah sebaiknya lebih selektif dalam memberikan pembiayaan murabahah kepada nasabah agar dapat mengurangi tingkat resiko yang dialami, dalam proses pencatatan masih ada yang harus dibenahi seperti tidak mencatat persediaan barang pada saat pengadaan barang.

PT BRI syariah dan BMT Maslahah Sidogiri diharapkan dapat tetap menjalankan kegiatan pencatatan dan penyusunan laporan akuntansinya sesuai dengan standar akuntansi yang berlaku yaitu PSAK No. 102 demi menjaga rasa kepercayaan dan keterbukaan nasabah/angggota.

Bagi peneliti selanjutnya disarankan agar penelitian ini lebih dikembangkan, dalam menganalisis penerapan akad murabahah secara keseluruhan dan lebih mendetail.

\section{DAFTAR PUSTAKA}

Al Quran dan Al Hadist

Al- Muslih, Abdullah, dan Ash-Shawi, Shalah, 2004. Fikih Ekonomi Keuangan Islam, Jakarta: Darul-haq.

Fauzan, Achmad. 2011. Pembiayaan Bermasalah Evaluasi Penetapan Metode Penentuan Harga Jual Beli Murabahah. Skripsi. Jakarta: FE UIN Jakarta.

Hertanto widodo, dkk, PAS (Pedoman Akuntansi Syariah): PADUAN PRAKTIS OPERASIONAL BMT (Bandung: Mizan Anggota IKAPI, 2000), cetakan kedua.

IAI, Standar Akuntansi Keuangan PER 1 Juli 2009 (Jakarta : SalembaEmpat, 2009) PSAK 102.

Ilmi, Makhalul. 2002. Teori dan Praktek Lembaga Mikro Keuangan Syariah. UUI Press.

Indrus, Muhammad. 2009. Metode Penelitian Ilmu Sosial Pendekatan Kualitatif dan Kuantitatif. Edisi kedua. Yogyakarta: Penerbitan Erlangga.

Karim, Adiwarman. 2004. Bank Islam: Analisis Fiqih edisi kedua. Jakarta: Kharisma Putra Utama Offset. 
Nurhayati, Sri \& Wasilah. 2012. Akuntansi Syariah di Indonesia (edisi 2 revisi). Jakarta: Salemba Empat.

Nurboko, Cholid \& Achmadi, Abu. 2007. Metodologi Penelitian. Jakarta: Bumi Aksara.

Oktavia, Nelly Nurilmi. 2010 Penerapan PSAK 102 pada Perlakuan Akuntansi Pengakuan

Pendapatan untuk Pembiayaan Murabahah Pada Koperasi Syariah. Skripsi. Sekolah Tinggi Ilmu Perbanas.

Ridwan. 2004. Metode Riset. Jakarta: Rineka Cipta.

Sri Nurhayati \& Wasilah. 2009. Akuntansi Syariah di Indonesia. Edisi 2. Jakarta: Salemba Empat.

Sugeng, Widodo. 2010. Seluk Beluk Jual Beli Murabahah Prespektif Aplikatif. Yogyakarta: Asgar Chapter.

Sugiyono, 2011. Metode Penelitian Kuantitatif dan Kualitatif dan R\&D. Bandung: Alfabeta.

Wiroso. 2011. Akuntansi Transaksi Syariah. Jakarta: Ikatan Akuntan Indonesia. 